\title{
DISKUSSIE MET LOADER, J. A.: DIE CHRISTUSPREDIKING VAN DIE OU TESTAMENT, (IN DIE SKRIFLIG, JUNIE 1981)
}

Ek begin by 'n voetnota van Loader (N14 op p. 11) waarin hy sê dat hy dit onbegryplik vind dat ek hom daarvan kan beskuldig dat hy as vertrekpunt die kritiese wetenskap neem wat koubloedig wil ontleed en sy eie resultate as die alleen gesagvolle wil aandien met die doel om in die Bybel „agter die oënskynlike boodskap die waarheid te ontdek".

Dit is weer vir my onbegryplik wat sy voetnota met die stelling wat hy in sy artikel geponeer, te doen het. Hy stel op bladsy 7 "Gegewe dat ons die Ou Testament kan lees en in sy konteks kan verstaan, is die eerste stap 'n geloofsbelydenis. Die God van Abraham, Isak en Jakob, die God van die Ou Testament, is dieselfde as die Vader van Jesus Christus en God van die Nuwe Testament. Dit kan nie rasioneel bewys of uitgeredeneer word nie - dit is 'n saak van geloof". In my artikel was die geloof van wetenskaplikes en nog minder hulle belydenis aangaande God onder bespreking. Ek weier om enige oordeel oor ander uit te spreek en wil graag die eerste wees om hulle Godsvrug te erken met deemoedige belydenis van my eie sondigheid.

My artikel het kritiek gelewer op diegene wat skeiding wil maak tussen die werk van die Heilige Gees en van die mense wat Hy gedrywe het om die Woord op skrif te stel. Die menslike skrywers word so menslik voorgestel asof hulle getuienisse en geskrifte al die eienaardighede en swakhede wat in menslike nadenke en literatuur voorkom, toon. Dit gaan om Skrifuitleg.

Verder het ek diegene selfversekerd genoem wat meen dat hulle historiese- en literêre metodes die alfa en omega van Skrifuitleg sou wees en gou om die etiket „fundamentalisme” om ander te hang wat hulle opvattinge nie deel nie en 'n meer konserwatiewe vertrekpunt het. Die geleerders word dan beskuldig dat hulle in hulle "fundamentalisme die handhawing van die ortodokse en reformatoriese tradisie in die weg staan". Die geleerdes is o.a. J. D. du Toit, S. J. du Plessis en J. H. Kroeze.

My artikel eindig met ,sulke uitsprake bring wantroue in en afkeur van die kritiese wetenskap wat koudbloedig wil ontleed en sy eie resultate as die alleengesagvolle wil aandien." Dit was 'n beoordeling oor die bepaalde gebruik van die "kritiese-metodes".

Die artikel van Loader het my nie juis tot ander insigte gebring nie. Hy het dit oor die Christusprediking in die Ou Testament.

Hy stel tereg dat sy belydenis inhou dat „Hy (d.i. God) in die geskiedenis en godsdiens van Israel heengewerk het na die koms van sy Seun". Dit is egter belangrik om hier te verstaan wat hy met „heenwerk" bedoel. „Die inspirasie beteken dan nie die meganiese voorstu van die skrywerspenne nie, maar die leidende teenwoordigheid van God in die vorming van die hele tradisie." Sonder om die verstaanmoontlikhede van sy woord tradisie te wil ontleed (of dit menslike tradisie, die nadenke en vertolking van die gebeure, teologie, die oorlewering van die gesagvolle Woord is?) is dit opmerklik dat 
hy nie klem lê op die openbaring van God in woord en daad nie. Word hierdie "meganiese" optrede van God erken of ontken?

Uit bogenoemde is dit al duidelik dat hy met 'n paar uitsprake begin waaroor ek vraagtekens wil stel. - Tussen hakies: hy praat van 'n „vroeg-Christelike tradisie", dit is nou die Nuwe-Testamentiese getuienis. Ek sou hier weer die vraag wil stel: Is die belangrikste gebeure in die nuwe bedeling nie die daadwerklike konkrete (,meganiese") openbaring van God in Christus Jesus nie? Ons het nie net 'n klomp „tradisies” (wat dit ook al mag beteken) van Hom nie! -

Maar kom ons volg Loader verder. Die Ou Testamentiese „tradisie" het volgens hom wel 'n bydrae te lewer ten opsigte van die Christusprediking maar dit is ,nie 'n saak van een tema of groep motiewe of aspekte of tekste nie, maar 'n funksionele saak" (9) (Sy kursivering). Dit gaan nou oor die funksionele. H A T omskrywe funksionele as dit wat betrekking het op of behoort tot 'n funksie of funksies en funksie word omskrywe as die werk of werking. Ek probeer nou om dit wat Loader geskrywe het, te verstaan. Die Ou Testamentiese „tradisies" is 'n werkende saak, 'n werkende ding. Dit is so 'n werkpot waarin tradisies ,en uitsprake" rou en ongaar gekook is en die produk daarvan moet weer in positiewe of negatiewe opsigte ge,,interpreteer" word(9). Hoe 'n mens die produk van die werkende (funksionele) Ou Testamentiese tradisies (die Ou Testament het ,so 'n vooruitwerkende funksie") moet verklaar hang nie af van 'n bepaalde uitleg van die Ou Testament nie" maar ,van 'n geloofsoortuiging"(9). „Hulle (dit is die mense van die Nuwe Testament") het dan die gewone onwetenskaplike vertolkingstegnieke van hul tyd gebruik omdat dit 'n nuttige manier was om Hom aan die mense van destyds te verkondig nie nie omdat dit ' $n$ dringende bewys van die identiteit van Jesus was nie"(9) (My kursivering). Ek moet dus hieruit aflei dat die (ongaar) werkende Ou Testamentiese tradisies geen betroubare getuienis van Christus gee nie (?) "... ons (kan) nie sommer die Nuwe-Testamentiese interpretasie van Ou Testamentiese tekste as korrekte weergawes van die betekenis van die betrokke passasies aanvaar nie"(9).

As voorbeeld word na Mt. $1: 23$ verwys. Jes. $7: 14$ word as bewys van die maagdelike geboorte van Christus aangehaal maar Loader stel dat calma in Jes. 7 nie maagd beteken nie en dat dit niks met die ,,ideale messias" te doen het nie. Dit is alleen ,, die ambivalente teken van heil en onheil in die Siro-Efraimitiese oorlog" (10). Matteus is dus onwetenskaplik en verkeerd en bewys niks. Dit was ,net 'n nuttige manier om Hom aan die mense van destyds te verkondig" (9). In daardie tyd sou hulle met sulke praatjies (,bewyse") te vrede wees. Ons weet beter! (Sou dit nie beter gewees het om op die aard van die profesieë te let nie? Daar is immers 'n primêre vervulling en uiteindelik 'n absolute vervulling as die jonkvrnu in die mees volkome sin, naamlik 'n maagd, 'n kind in die wêreld bring!)

Maar ' $n$ tweede voorbeeld. Dit is vir Loader meer aanneemlik ,dat die Israelitiese verwagtings van 'n ideale messias in 'n politieke teologie as in 'n kultiese teologie ontstaan het" (2). Die Messiasver- 
wagting is dus gebore in die politiese nadenke van mense. Dit is nie deur God geopenbaar nie. God het nie volkome en genoegsaam deur Natan (1 Sam. 7) en die koningspsalms gespreek nie (2). Daar was ook nog kritiek van die deuteronomistiese teologie (weer die teologiese nadenke van mense). "So ontstaan daar 'n geweldige spanning: Die koningskap móét bly staan (Natan, koningspsalms); die koningskap kan nie bly bestaan nie (oordeelsprediking). En hieruit ontstaan die verwagting van 'n toekomstige Dawidiese messias wat die vervalle hut van Dawid sou oprig en 'n ideale vors sou wees"(2). Dus in die werkpot van menslike oorwegings ontstaan 'n soort polities-teologies-messias begrip wat in wesenlike sin niks met Christus te doen het nie. Dit is ook merkwaardig dat die oorsprong van die messiasbegrip in die koningstydperk gesoek word. Is Gen. $3: 15$ net 'n sage van die Jahwis of is die beloftes in Gen. $12: 1-3$ of $17: 6$ die teologie van die Priester(?) in die ballingskap?

Bogenoemde vrae en opmerkings bring my tot die vraag: Hoe beskou Loader dan die Ou Testament. Hy sê , die ganse Ou-Testamentiese tradisie is die geestelike matrix (moeder) van sy (Christus) menslike lewe" (8). Hy praat selfs gekwalifiseerd van beloftes en vervulling (10), maar ,die skopus van elks Ou-Testamentiese teks (moet) in die perspektief van die Christusgebeure beoordeel" (10) word. Samevattend lyk dit vir my of hy die Ou Testament as 'n bundel Israelitiese tradisies besien wat die agtergrond vorm van nog 'n klomp nuwe Testamentiese tradisies wat in en na die tyd van Christus ontstaan het. In die Ou Testament is daar geen helder Godsopenbaring aangaande Christus nie maar vae politiese modelle wat geskik gelyk het om die volk van die Nuwe Testament mee te vrede te stel. Vir ons is dit dan interessante agtergrondsgeskiedenis van 'n ,,Messias-idee'.

'n Laaste opmerking:

In my kerkbladartikel het ek teen die gevolge van oorbeklemtoonde histories- en literêre-kritiese metodes gewaarsku. Die resultate van Loader se verklaring van die Christusprediking in die Ou Testamentiese tradisies laat my weer eens sê dat sulke uitsprake wantroue en afkeur in die kritiese wetenskap bring.

F. N. Lion-Cachet 